\title{
Effects of Green Tea Extract and Lactobacillus Casei Strain Shirota on Levels of Serum Minerals, Cholesterol, Triglycerides, Glucose and Lactate in Rats Fed on High-carbohydrate and High-lipid Diets
}

\author{
Yeșil Cay Ekstraktı ve Lactobacillus Casei Strain Shirota'nın Yüksek Karbonhidrat ve Lipit Içerikli Yeșil \\ Diyetle Beslenen Ratlarda Serum Mineral, Kolesterol, Trigliserid, Glikoz ve Laktat Seviyeleri Üzerine Etkileri
}

\author{
Turan Karaca', Fahri Bayıroğlư², Mustafa Cemek3 ${ }^{3}$, Bahat Comba' ${ }^{2}$, Ahmet Ayaz ${ }^{3}$, İhsan Karaboğa ${ }^{1}$ \\ ${ }^{1}$ University of Trakya, Faculty of Medicine, Department of Histology and Embryology, Edirne, Turkey, ${ }^{2}$ University of Y ürüncü Yul, Faculty of \\ Veterinary Medicine, Department of Physiology, Van, Turkey, ${ }^{3}$ University of Yildz Technical, Faculty of Chem. and Met. Eng., Department of \\ Bioengineering (Division of Biochemistry), Istanbul, Turkey
}

\begin{abstract}
AIM: The objective of the present study was to evaluate the effects of green tea extract and Lactobacillus casei strain Shirota on levels of serum minerals ( $\mathrm{Ca}, \mathrm{Cu}, \mathrm{Zn}, \mathrm{Fe}, \mathrm{Mg}$ and $\mathrm{Mn}$ ), cholesterol, triglyceride, glucose and lactate in rats on high carbohydrate and lipid diets.
\end{abstract}

METHODS: Thirty five healthy Wistar albino rats were used, five in each of seven experimental groups: control (group A), high-carbohydrate diet (group B), high-carbohydrate diet supplemented with probiotic bacteria for 8 weeks - Lactobacillus casei strain Shirota (group C), high-carbohydrate diet supplemented with green tea extract for 8 weeks - in drinking water: $100 \mathrm{mg} / \mathrm{kg} /$ day (group D), high-lipid diet for 8 weeks (group E), high-lipid diet supplemented with probiotic bacteria for 8 weeks (group F), high-lipid diet supplemented with green tea extract for 8 weeks- in drinking water: $100 \mathrm{mg} / \mathrm{kg} /$ day (group G).

RESULTS: A significant increase $(p<0.05)$ in serum cholesterol was observed in groups treated with high-lipid, and high-lipid + green tea extracts ( $E$ and $G)$ compared with other groups $(P<0.05)$. Serum triglyceride levels were significantly lower in the high-carbohydrate + probiotic group $(C)$ than in other groups $(p<0.05)$. High-calorie diet, green tea extract and probiotic bacteria had no influence on serum lactate levels in any of the groups. Serum Ca levels decreased significantly only in the high-carbohydrate diet group $(p<0.05)$. However, serum $\mathrm{Zn}$ and Fe concentrations increased significantly in the high-lipid and high-lipid plus probiotic bacteria groups, respectively $(p<0.05$ and 0.01 ). Serum $\mathrm{Mg}$ levels were significantly lower in all experimental groups compared to the control group $(P<0.01)$. L. casei strain Shirota and the green tea extract, significantly lowered serum glucose levels in the highcarbohydrate groups compared to high-lipid groups $(p<0.05)$.

CONCLUSION: The green tea extract and L. casei strain Shirota decreases serum glucose and triglyceride levels in rats fed on high-calorie diets.

Key words: high-calorie diet; green tea; probiotic bacteria; serum mineral levels

Turan Karaca, Balkan Yerleskesi 22030 Edirne, Türkiye. Tel. 02842357653

Email.turankaraca74@botmail.com

Geliș Taribi: 24.12.2012 • Kabul Taribi: 19.03.2013

\section{ÖZET}

AMAÇ: Bu çalıșmanın amacı, yeșil çay ekstraktı ve Lactobacillus casei strain Shirota'nın yüksek karbonhidrat ve lipit içerikli diyetle beslenen ratlarda serum mineralleri ( $\mathrm{Ca}, \mathrm{Cu}, \mathrm{Zn}, \mathrm{Fe}, \mathrm{Mg}$ and $\mathrm{Mn}$ ), kolesterol, trigliserid, glikoz ve laktat düzeyleri üzerine etkilerinin araștırılmasıdır.

YÖNTEM: Otuzbeș sağlıklı Wistar albino rat her grupta 5 hayvan olacak șekilde 7 gruba ayrıldı: Kontrol grubu (A), yüksek-karbonhidratı diyet grubu (B), yüksek karbonhidratı diyet ve 8 hafta süreyle probiyotik bakteri ilaveli grup-Lactobacillus casei strain Shirota (C), yüksek karbonhidratı diyet ve 8 hafta süreyle yeșil çay ekstraktı verilen grup (D), yüksek lipit içerikli diyet grubu (E), yüksek lipit içerikli diyet ve 8 hafta süreyle probiyotik bakteri ilaveli grup-Lactobacillus casei strain Shirota $(F)$ ve yüksek lipit içerikli diyet ve 8 hafta süreyle yeșil çay ekstraktı ilaveli grup (G).

BULGULAR: Serum kolesterol seviyesinin yüksek lipit ve yüksek lipit + yeșil çay ekstraktı ilaveli gruplarda (grup E ve G) kontrole ve diğer deneme gruplarına göre anlamlı olarak artığı tespit edildi $(p<0.05)$. Serum trigliserid seviyesi yüksek karbonhidrat + probiyotik ilaveli grupta (grup C) diğer deneme gruplarından anlamlı olarak düșüktü $(p<0.05)$. Yüksek kalorili diyet, yeșil çay ekstraktı ve probiyotik ilavesinin gruplarda serum laktat seviyesi üzerine herhangi bir etkisinin olmadığı görüldü. Serum Ca düzeyinin yanlızca yüksek karbonhidrat içerikli diyet grubunda anlamlı olarak azaldığı tespit edildi $(p<0.05)$. Bununla birlikte, serum Zn ve Fe konsantrasyonlarının yüksek lipit ve yüksek lipit + probiyotik ilaveli gruplarda sırasıyla $p<0.05$ ve $P<0.01$ düzeylerinde anlamlı olarak artığı tespit edildi. Serum Mg seviyesinin tüm deneme gruplarında kontrole göre istatistiksel olarak anlamlı derecede azaldığı tespit edildi $(P<0.01)$. $L$. casei strain Shirota ve yeșil çay ekstraktı alınması yüksek karbonhidrat diyetli gruplarda serum glikoz seviyesini yüksek lipid diyetli gruba göre anlamlı olarak azalttığı belirlendi $(p<0.05)$.

SONUÇ: Yeșil çay ekstraktı ve L. casei strain Shirota kullanımının yüksek enerjili diyetle beslenen ratlarda kan glukoz ve trigliserid seviyelerini düșürücü etkisi vardır.

Anahtar kelimeler: yüksek kalorili diyet; yeșil çay; probiyotik bakteri; serum mineral seviyesi 


\section{Introduction}

Obesity has been linked to a wide variety of health problems including hypertension, dyslipidemia, cardiovascular diseases, hyperglycemia, diabetes mellitus, inflammation disorders and cancer, based on accumulation of visceral fat ${ }^{1,2}$. Previous studies have shown that high-fat diets trigger obesity under ad libitum feeding conditions ${ }^{3}$. A high-fat diet increased the sensitivity of insulin to stimulate adipocyte glucose uptake in a mouse strain that was genetically sensitive to developing dietary obesity ${ }^{4}$.

Tea (Camellia sinensis) is consumed worldwide and it is generally accepted that the tea is the most consumed beverage in the world ${ }^{5}$. Previous studies conducted in humans and animals have reported that the green tea and its components (catechins, flavonols, etc.) have many biological and biochemical advantageous effects of anti-obesity ${ }^{6}$, anti-diabetic ${ }^{7}$, anti-carcinogenesis $^{8}$, hypolipidemic ${ }^{5}$, anti-oxidative ${ }^{9}$, apoptosisinducing ${ }^{10}$, and anti-angiogenesis ${ }^{11}$. In addition, the consumption of green tea decreases serum levels of triacylglycerols and LDL cholesterol ${ }^{12}$, and increases the serum levels of HDL cholesterol ${ }^{13,14}$.

Probiotic colonies are the natural flora of their host's gastrointestinal track and they play critical roles in promoting health in humans and animals by blocking gastrointestinal pathogens, neutralizing food mutagens produced in colon, enhancing systemic immune response and dissolving intestinal dysfunction ${ }^{15}$.

Previous studies showed that oral administration of Lactobacillus casei decreased plasma glucose levels in mice ${ }^{16}$ and Bifidobacterium longum reduced serum cholesterol levels in rats ${ }^{15}$. Similar studies performed on humans showed the similar effect on blood lipids ${ }^{17}$.

Although the effects of consumption of green tea and some probiotics on serum mineral levels have been defined, their effects during high caloric diet intake were not thoroughly studied. In this present study we aimed to study the influence of high-fat and high-carbohydrate diets with or without the supplementation of probiotic bacteria and green tea extract on serum $\mathrm{Ca}, \mathrm{Cu}, \mathrm{Zn}, \mathrm{Fe}, \mathrm{Mg}$ and $\mathrm{Mn}$ levels in rats. The second objective of the study was to analyze the effects of consumption of probiotic bacteria and green tea extract on serum cholesterol, triglycerides, glucose and lactate levels during high calorie diet.

\section{Methods}

The study was performed in Yüzüncü Y1l University Faculty of Veterinary Medicine. All procedures were conducted according to the Yuzuncu Yil University Ethics Committee Statements on laboratory animals (Ethical approval decision number 2011-05).

\section{Animals and diets}

Thirty five healthy, male Wistar albino rats, weighting 200-260 $\mathrm{g}$ and averaging 8 weeks old were used in this study. Animals were housed three in a polycarbonate cage in temperature controlled rooms $\left(21 \pm 2^{\circ} \mathrm{C}\right)$ with a 12-hour light/dark cycle, fed with standard rat pellets (Vangölü animal food product co., Van, Turkey), and given water ad libitum for an adaptation period of 10 days.

The rats were randomly allocated into one of the seven experimental groups (Table 1): group A (control), group B (high-carbohydrate diet), group C (high-carbohydrate diet supplemented with probiotic bacteria for 8 weeks - Lactobacillus casei strain Shirota), group D (high-carbohydrate diet supplemented with green tea extract for 8 weeks - in drinking water: 100 $\mathrm{mg} / \mathrm{kg} /$ day), group E (high-lipid diet for 8 weeks), group F (high-lipid diet supplemented with probiotic bacteria for 8 weeks), group $G$ (high-lipid diet supplemented with green tea extract for 8 weeks- in drinking water: $100 \mathrm{mg} / \mathrm{kg} /$ day). Thus, each group contained five animals.

The control group was fed with the standard pelleted $\operatorname{diet}(362.0 \mathrm{kcal} / 100 \mathrm{~g})$ containing a dry weight composition of $18 \%$ protein, $76 \%$ carbohydrate and $6 \%$ lipid. The experimental groups were fed with either a carbohydrate-rich hypercaloric diet or a lipid-rich hypercaloric diet both composed of casein, starch, sucrose, straw, L-methionin, corn oil, animal oil (tallow) and vitamin-mineral mix. The carbohydrate-rich

Table 1. The study groups and consumed diets.

\begin{tabular}{lll}
\hline Group A & $n=5$ Control (standard rat pellets feed) \\
Group B & $n=5$ High-carbohydrate diet \\
Group C & $n=5$ High-carbohydrate diet + Lactobacillus casei strain Shirota \\
Group D & $n=5$ High-carbohydrate diet + Green tea extract \\
Group E & $n=5$ High-lipid diet \\
Group F & $n=5$ High-lipid diet + Lactobacillus casei strain Shirota \\
Group G & $n=5$ High-lipid diet + Green tea extract
\end{tabular}

Group C $n=5$ High-carbohydrate diet + Lactobacillus casei strain Shirota

Group D $\mathrm{n}=5$ High-carbohydrate diet + Green tea extract

Group E $\mathrm{n}=5$ High-lipid diet

Group $G \quad n=5$ High-lipid diet + Green tea extract 
hypercaloric diet contained a total of $4100 \mathrm{kcal} / 100$ g, with a dry weight composition of $56 \%$ carbohydrate. The lipid-rich hypercaloric diet contained a total of $4200 \mathrm{kcal} / 100 \mathrm{~g}$ with a dry weight composition of $50 \%$ lipid (Table 2 ).

At the end of the experiments all animals were sacrificed by decapitation.

\section{Biochemical measurements}

Blood samples were obtained at the beginning and the end of the experimental period. The blood samples were carefully collected and stored at $-80^{\circ} \mathrm{C}$ prior to analysis. The levels of $\mathrm{Ca}, \mathrm{Cu}, \mathrm{Zn}, \mathrm{Fe}, \mathrm{Mg}$ and $\mathrm{Mn}$ were measured by using an UV-Spectrophotometer (Shimadzu UV-1201, Japan). The samples were diluted in water before measuring the levels of copper and manganese. All samples were analyzed in triplicate.

Cholesterol (Biolabo, 80106), glucose (Biolabo, 80009) and triglyceride (Ben SRL- TG381, Italy) levels were determined with commercial kits adapted to a Shimadzu UV-1201, UV-Vis Spectrophotometer (Japan). Serum lactate levels were also studied by using commercial kits (Spinreact) ${ }^{18}$.

\section{Statistical analysis}

The data were expressed as mean \pm standard deviation (SD), and analyzed by repeated measures of variance. A Tukey test was used to test the differences among means when an analysis of variance (ANOVA) indicated a statistical significance $(\mathrm{p}<0.05$ or 0.01).

Table 2. The composition of the experimental diets

\begin{tabular}{lcc}
\hline & \multicolumn{2}{c}{$\%$ of total diet } \\
Ingredients & High-carbohydrate diet & High-lipid diet \\
\hline Casein & 11 & 11 \\
Starch & 15 & 6 \\
Sucrose & 56 & 50 \\
Straw & 2.2 & 8.2 \\
L-Methionin & 0.1 & 0.1 \\
Corn oil & 5.5 & 10 \\
Animal oil (Tallow) & 5.5 & 10 \\
Vitamin-Mineral Mix & 4.7 & 4.7 \\
Crude protein & 10.45 & 10.48 \\
Metabolic Energy (kcal) & $4100 / 100 \mathrm{~g}$ & $4200 / 100 \mathrm{~g}$ \\
\hline
\end{tabular}

\section{Results}

\section{Blood mineral levels}

The mineral, cholesterol, triglycerides, glucose and lactate levels of the rats were presented in Tables 3 and 4. Serum Ca levels were significantly decreased after 8 weeks in the carbohydrate-rich diet group (B) $(p<0.05)$, however, there were no significant changes within either the control group or the other treatment groups.

Serum concentrations of $\mathrm{Cu}$ decreased in groups B and $C$ compared to the other experimental groups (D-G) $(p<0.01)$. Serum Zn levels were significantly increased after the lipid-rich diet $(\mathrm{E})$ and the lipid-rich diet plus green tea extract $(G)$ compared with other groups $(p<0.01)$. Serum Fe levels were significantly decreased in the carbohydrate-rich diet plus green tea group (D) and lipid-rich plus green tea group $(G)$ $(p<0.01)$. In addition, the serum concentration of $\mathrm{Mg}$ significantly decreased in the lipid-rich plus green tea extract group $(G)$ compared with other treatment groups $(\mathrm{B}-\mathrm{F})(p<0.01)$. Serum $\mathrm{Mn}$ levels were higher in lipid-rich plus probiotic bacteria group $(\mathrm{F})$, and lipid-rich plus green tea groups $(\mathrm{G})$ compared to other groups $(\mathrm{p}<0.01$, Table 3$)$.

\section{Cholesterol and triglyceride levels}

Serum cholesterol levels increased in the high-lipid group $(E)$ rats $(p<0.05)$, however, there were no changes in other experimental groups. Serum triglyceride levels were significantly increased in the experimental groups compared to control group $(p<0.05)$. However, in group $\mathrm{D}$ serum triglyceride levels were significantly decreased compared with the other high-calorie and treatment groups $(p<0.01)$ (Table 4).

\section{Blood glucose and lactate levels}

Serum glucose levels increased in the experimental groups compared to the control group. Serum glucose levels were lower in the carbohydrate plus probiotic (group C), and carbohydrate plus green tea (group D) groups than in the other experimental groups $(p<0.01)$. No changes were observed in serum lactate levels in either the high-carbohydrate or the high-lipid diet groups with either the supplementation of green tea or probiotic bacteria in comparison with the control group ( $p>0.05$, Table 4$)$. 
Table 3. The effects of high energy diets and the supplementation of the probiotic bacteria and the green tea extracts on some minerals. The data was presented as mean \pm standard deviation.

\begin{tabular}{|c|c|c|c|c|c|c|c|}
\hline Group name & Group code & $\mathrm{Ca}$ & $\mathrm{Cu}$ & $\mathrm{Zn}$ & $\mathrm{Fe}$ & $\mathrm{Mg}$ & $\mathrm{Mn}$ \\
\hline Control & $\mathrm{A}$ & $90.37 \pm 6.0$ & $2.13 \pm 0.8^{b}$ & $1.59 \pm 0.1^{\mathrm{e}}$ & $3.34 \pm 1.0$ & $30.01 \pm 8.2^{g}$ & $0.09 \pm 0.02^{i}$ \\
\hline Carbohydrate & B & $78.52 \pm 5.3^{\mathrm{a}}$ & $1.32 \pm 0.01^{c}$ & $1.13 \pm 0.06$ & $3.46 \pm 0.9$ & $20.16 \pm 7.4$ & $0.09 \pm 0.01^{i}$ \\
\hline Carbohydrate + Probiotic & C & $88.75 \pm 10.2$ & $1.42 \pm 0.03^{c}$ & $1.24 \pm 0.02$ & $3.15 \pm 1.1$ & $20.28 \pm 6.3$ & $0.11 \pm 0.01$ \\
\hline Carbohydrate + Green tea & D & $86.92 \pm 12.4$ & $1.65 \pm 0.05$ & $1.10 \pm 0.04$ & $2.78 \pm 0.9^{f}$ & $20.02 \pm 6.8$ & $0.10 \pm 0.02$ \\
\hline Lipid & $\mathrm{E}$ & $89.02 \pm 9.8$ & $1.74 \pm 0.02$ & $2.09 \pm 0.7^{d}$ & $3.49 \pm 1.0$ & $20.21 \pm 5.4$ & $0.11 \pm 0.03$ \\
\hline Lipid+Probitic & $\mathrm{F}$ & $93.92 \pm 11.4$ & $1.71 \pm 0.1$ & $1.85 \pm 0.03$ & $4.05 \pm 0.9^{*}$ & $21.12 \pm 6.8$ & $0.18 \pm 0.04^{\mathrm{h}}$ \\
\hline Lipid+green tea & G & $88.71 \pm 6.3$ & $1.55 \pm 0.01$ & $2.41 \pm 0.9^{d}$ & $2.26 \pm 0.8^{f}$ & $10.71 \pm 3.1^{\Upsilon 1}$ & $0.18 \pm 0.01^{\mathrm{h}}$ \\
\hline
\end{tabular}

Table 4. The effects of high energy diets and the supplementation of the probiotic bacteria and the green tea extracts on serum glucose and lipid levels. The data was presented as mean \pm standard deviation.

\begin{tabular}{lccccc}
\hline Group name & Group code & Cholesterol & Triglycerides & Glucose & Lactate \\
\hline Control & $\mathrm{A}$ & $108.7 \pm 8$ & $40.1 \pm 12^{\mathrm{c}}$ & $88.5 \pm 10^{\mathrm{d}}$ & $10.13 \pm 3$ \\
Carbohydrate & $\mathrm{B}$ & $114.6 \pm 15$ & $129.6 \pm 23$ & $166.5 \pm 33$ & $11.03 \pm 2$ \\
Carbohydrate + Probiotic & $\mathrm{C}$ & $111.2 \pm 20$ & $127.2 \pm 16$ & $114.8 \pm 11.5^{\mathrm{e}}$ & $14.56 \pm 5$ \\
Carbohydrate + green tea & $\mathrm{D}$ & $118.3 \pm 14$ & $51.2 \pm 9^{\mathrm{b}}$ & $111.6 \pm 8^{\mathrm{e}}$ & $12.55 \pm 2$ \\
Lipid & $\mathrm{E}$ & $137.7 \pm 10^{\mathrm{a}}$ & $146.1 \pm 19$ & $155.9 \pm 20$ & $14.08 \pm 4$ \\
Lipid + probitic & $\mathrm{F}$ & $123.4 \pm 13$ & $130.7 \pm 21$ & $133.6 \pm 25$ & $11.57 \pm 3$ \\
Lipid + Green tea & $\mathrm{G}$ & $128.1 \pm 9^{\mathrm{a}}$ & $135.8 \pm 24$ & $135.6 \pm 27$ & $8.89 \pm 2$ \\
\hline a: $P<0.05$ compared to group $\mathrm{F} ;$; $: P<0.05$ compared to experimental groups; $:$ : $: P<0.01$ compared to experimental groups; : $: P<0.05$ compared to other experimental groups.
\end{tabular}

\section{Discussion}

Obesity is an important health problem, and its prevalence is increasing worldwide. Obese individuals have been shown to have a higher incidence of infections and infection related mortality, and several types of cancer occur more frequently in obese populations ${ }^{2}$. In a previous study it was suggested that high fat diet-induced overweight rats present an altered immune response ${ }^{19}$. Milagro et al. showed that a high fat diet might develop obesity, hyperglycemia, and fatty liver and oxidative stress ${ }^{20}$.

In our study, we observed that a high-calorie diet had also an impact on serum mineral levels. Group B (high-carbohydrate diet) displayed decreased serum $\mathrm{Ca}$ levels compared to the control and other high-calorie diet groups $(\mathrm{p}<0.05)$. However, supplementation of probiotic bacteria significantly increased serum Fe levels in the high-lipid diet group (F) $(\mathrm{p}<0.01)$. In addition, supplementation of green tea extract significantly decreased serum Fe levels in the high-carbohydrate group (D) and high-lipid diet group $(G)(p<0.01)$.
High-lipid diet groups supplemented with green tea in their drinking water had an approximately 1.5 -fold decreased levels of serum $\mathrm{Mg}$ after 8 weeks compared with rats fed the basal diet. Our data also showed that feeding the rats with a high-carbohydrate diet decreased serum $\mathrm{Ca}, \mathrm{Cu}, \mathrm{Zn}$ and $\mathrm{Mg}$ levels.

In our study the serum $\mathrm{Cu}$ levels were significantly lower in all of the high-calorie and supplementation diet groups compared with the control group. However, serum $\mathrm{Zn}$ levels decreased in carbohydrate-rich diet groups with or without probiotic bacteria and green tea supplementation. The oxidant effect of a high-calorie diet has been associated with the impairment of obesity related issues such as suppressor effect on immunity. Lamas et al. suggested that weight loss after caloric restriction may restore immune function in rats ${ }^{2}$.

Copper and manganese are required in small amounts as components of antioxidant enzymes. The primary role for copper is catalytic, as it is found in many copper metalloenzymes, e.g., ferroxidase, CuZn-superoxide dismutase (CuZn-SOD), 
cytochrome C oxidase, dopamine hydroxylase, and diamine oxidase ${ }^{21}$. Ferroxidases are copper-containing enzymes found in plasma that oxidize ferrous iron, i.e., $\mathrm{Fe}^{2+} \rightarrow \mathrm{Fe}^{3+}$. Therefore, determining their plasma level may contribute to better assessing the health and nutritional status of certain populations ${ }^{22}$. Under conditions of oxidative stress, plasma copper increases predominantly in the form of ferroxidase I and assists with the removal of any unbound iron in the plasma ${ }^{21,23}$.

Previous studies have suggested that, under acute hyperglycemic state, plasma zinc status alters the interrelationship between plasma glucose and zinc concentrations during oral glucose tolerance test (OGT'T) in obese individuals ${ }^{24}$. However, the same study showed that plasma zinc levels were not changed during OGTT in obese individuals ${ }^{24}$. Sambol et al. showed that Fe plasma levels were lower in non-vegetarians than in vegans and lacto-ovovegetarians ${ }^{25}$. In the present study, serum iron levels were statistically decreased in carbohydrate rich diet plus green tea, and lipid rich diet plus green tea compared to carbohydrate and lipid rich diet groups (Table 3). In addition the lipid-induced diet caused a marked increase in serum $\mathrm{Zn}$ levels that was speculated to be responsible for inflammatory changes.

Serum zinc is the most commonly used indicator and it rapidly decreases in the presence of inflammation. Serum insulin-like growth factor (IGF) concentrations are low in zinc-deficient rats ${ }^{26}$. Similarly, zinc supplementation can raise IGF concentrations in children considered undernourished or moderately zinc deficient ${ }^{27}$.

The main indices of iron status are blood hemoglobin and concentrations of serum ferritin and transferrin receptor. Total serum iron is also used as a measure of iron status, however as in the case of zinc, serum iron is strongly depressed by inflammation ${ }^{21,28}$. The antihypertensive effects of magnesium supplements in hypertensive individuals are controversial ${ }^{29}$.

Karmakar et al. suggested that the high-fat diet induced increases in serum glucose, cholesterol, triglyceride, LDL and VLDL levels, and a decrease in serum HDL levels ${ }^{5}$. However, all these increases were found to be reversed significantly with black tea extract supplementation. The previous studies reported that the hypoglycemic effect of tea was attributed to the presence of polyphenols, catechins and a watersoluble polysaccharide fraction ${ }^{6,30,31}$. Similar studies reported that black and green tea extract have been found to decrease plasma triglycerol, cholesterol and LDL-cholesterol in rats, and green tea epigallocatechin gallate inhibited obesity ${ }^{32}$.

Table 4 summarizes the concentrations of cholesterol, triglycerides, glucose and lactate in all study groups. In our study, the levels of glucose, triglycerides, lactate and cholesterol were measured after 8 weeks. Blood glucose levels of the carbohydrate plus probiotic (C) and carbohydrate plus green tea diet groups (D) were lower than of the other experimental groups. These results suggest that the dietary supplementation of $L$. casei strain Shirota and green tea extract may prevent or delay the development of hyperglycemia in obese rats induced by a high-carbohydrate diet. The serum glucose values were significantly higher in the B, E, F and G groups $(p<0.05)$ in comparison with these two groups.

The serum cholesterol levels were higher in the highlipid diet group (E) compared with the other experimental groups $(p<0.01)$. The serum triglyceride levels of group $\mathrm{D}$ were lower than the serum triglyceride levels of all other experimental groups $(\mathrm{p}<0.05)$.

Diets containing high amounts of carbohydrate, such as fructose, have been shown to cause weight gain and increase plasma triglyceride concentrations ${ }^{33,34}$. In a previous study it was shown that the rats fed on high-carbohydrate diets containing either a fructose/ glucose mixture or honey had a hypertriglyceridemia reaction and an increased lipid peroxidation ${ }^{35}$.

Previous studies in humans and animals have shown that probiotics or the products of its fermentation may have beneficial hypocholesterolemic and hypoglycemic effects on lipid metabolism of their hosts $^{36,37}$. Rodas et al. reported that L. acidophilus ATCC 43121 supplementation was beneficial in lowering serum cholesterol and LDL cholesterol concentrations in pigs. Our study indicated that the rats fed on a high-carbohydrate diet and supplemented with $L$. casei strain Sbirota had a decrease in their serum glucose levels. However, the rats fed on a highlipid diet did not show changes in serum cholesterol or triglyceride levels ${ }^{38}$. Wang et al. suggested that L. plantarum MA2 decreased serum levels of total cholesterol, LDL cholesterol and triglyceride levels in rats fed on high-cholesterol diets ${ }^{39}$.

In conclusion, according to our experimental study a high-carbohydrate diet significantly decreased 
the serum Ca levels in rats. A high lipid and a high lipid with probiotics diet increased the $\mathrm{Zn}$ and Fe concentrations. The consumption of the green tea extract and L. casei strain Shirota lower the serum glucose and triglyceride levels in rats on high-calorie diets.

\section{Acknowledgement}

The study was supported by a grant from the Head of the Scientific Research Projects, University of Yuzuncu Yil, with a Grant Number VF-2009-B020.

\section{References}

1. Fujikawa T, Hirata T, Wada A, et al., Chronic administration of Eucommia leaf stimulates metabolic function of rats across several organs. Brit J Nutr 2010; 104:1868-77.

2. Lamas O, Martinez JA, Marti A. Energy restriction restores the impaired immune response in overweight (cafeteria) rats. J Nutr Biochem 2004; 15:418-25.

3. Bray GA, Popkin BM. Dietary fat intake does affect obesity. Am J Clin Nutr 1998; 68:1157-73.

4. Eberhart GP, West DB, Boozer CN. Insulin sensitivity of adipocytes from inbred mouse strains resistant or sensitive to diet-induced obesity. Am J Physiol 1994; 266:R1423-8.

5. Karmakar S, Das D, Maiti A, et al. Black tea prevents high fat diet-induced non-alcoholic steatohepatitis. Phytother Res 2011; 25:1073-81. DOI: 10.1002/ptr.3466.

6. Zhou X, Wang D, Sun P, et al. Effects of soluble tea polysaccharides on hyperglycemia in alloxan-diabetic mice. J Agr Food Chem 2007; 55: 5523-8.

7. Karaca T, Yoruk M, Yoruk IH et al. Effects of extract of green tea and ginseng on pancreatic beta cells and levels of serum glucose, insulin, cholesterol and triglycerides in rats with experimentally streptozotocin-induced diabetes: A histochemical and immunohistochemical study. J Anim Vet Adv 2010; 9:102-7.

8. Hara Y, Matsuzaki S, Nakamura K. Anti-tumor activity of green tea catechins. J Jpn Soc Nutr Food Sci 1989; 42:39-45.

9. Matsuzaki T, Hara Y. Antioxidative activity of tea leaf catechins. J Agr Chem Soc Jpn [Nihon Nogei Kagakkai-shi] 1985; 59: 129-34.

10. Ahmad N, Fayes DK, Nieminen AL, et al. Green tea constituent epigallocatechin-3-gallate and induction of apoptosis and cell cycle arrest in human carcinoma cells. J Natl Can I 1997; 89:1881-9.

11. Cao Y, Cao R. Angiogenesis inhibited by drinking tea. Nature 1999; 398:381.

12. Kono S, Shinchi K, Ikeda N. et al. Green tea consumption and serum lipid profiles: a cross-sectional study in Northern Kyushu, Japan. Prev Med 1992; 21: 526-31.
13. Chan PT, Fong WP, Cheung YN et al. Jasmine green tea epicatechins are hypolipidemic in hamsters (Mesocricetus auratus) fed a high fat diet. J Nutr 1999; 129:1094-101.

14. Imai K, Nakachi K. Cross sectional study of effects of drinking green tea on cardiovascular and liver diseases. Brit Med J 1995; 310:693-6.

15. Shin HS, Park SY, Lee DK, et al. Hypocholesterolemic effect of sonication-killed Bifidobacterium longum isolated from healthy adult Koreans in high cholesterol fed rats. Arch Pharm Res 2010; 33:1425-31.

16. Matsuzaki T, Yamazaki R, Hashimoto S, et al. Antidiabetic effect of an oral administration of Lactobacillus casei in a non-insulin dependent diabetes mellitus (NIDDM) model using KK-Ay mice. Endocr J 1997; 44:357- 65.

17. Taylor GR, Williams CM. Effects of probiotics and prebiotics on blood lipids. Brit J Nutr 1998; 80:225-30.

18. Gau N. Lactic acid. In: Kaplan A, editor. Clin Chem. St. Louis, Toronto: Princeton The C.V. Mosby Co.; pp. 418, 1040-1042, 1984.

19. Lamas O, Martinez JA, Marti A. T helper lymphopenia and decreased mitogenic response in cafeteria diet-induced obese rats. Nutr Res 2002; 22:496-507.

20. Milagro FI, Campion J, Martinez JA. Weight gain induced by high-fat feeding involves increased liver oxidative stress. Obesity 2006; 14:1118-23.

21. Northrop-Clewes CA, Thurnham DI. Monitoring micronutrients in cigarette smokers. Clin Chim Acta 2007; 377:14-38.

22. Sanchez C, Lopez-Jurado M, Aranda P. Plasma levels of copper, manganese and selenium in an adult population in southern Spain: Influence of age, obesity and lifestyle factors. Sci Total Environ 2010; 408:1014-20.

23. Smith C, Mitchinson MJ, Aruoma OI, et al. Stimulation of lipid peroxidation and hydroxyl-radical generation by the contents of human atherosclerotic lesions," Biochem J 1992; 286:901-5

24. Chen MD, Lin PY, Sheu WH. Zinc status in plasma of obese individuals during glucose administration. Biol Trace Elem Res 1997; 60:123-9.

25. S. Sambol Z, Stimac D, Orlic ZC et al. Haematological, biochemical and bone density parameters in vegetarians and non-vegetarians. W Indian Med J 2009; 58:51226.

26. Blostein-Fujii A, Di Silvestro RA, Frid D, et al. Short-term zinc supplementation in women with noninsulin-dependent diabetes mellitus: effects on plasma 5'-nucleotidase activities, insulin-like growth factor I concentrations, and lipoprotein oxidation rates in vitro. Am J Clin Nutr 1997; 66:639-42.

27. Ninh NX, Thissen JP, Collette L, et al. Zinc supplementation increases growth and circulating insulin like growth factor I (IGF-I) in growth-retarded Vietnamese children. Am J Clin Nutr 1996; 63:514-9.

28. World Health Organisation (WHO). Iron deficiency anemia assessment, prevention and control: a guide for programme managers. 2001; Geneva, WHO. 
29. Savica V, Bellinghieri G, Kopple JD. The effect of nutrition on blood pressure," Annu Rev Nutr 2010; 30:365-401.

30. Ramadan G, El-Beih NM, El-Ghffar EAA. Modulatory effects of black v. green tea aqueous extract on hyperglycaemia, hyperlipidaemia and liver dysfunction in diabetic and obese rat models. Brit J Nutr 2009; 102:1611-9.

31. Shimizu M, Kobayashi Y, Suzuki M. Regulation of intestinal glucose transport by tea catechij. Biofactors 2000; 13:61-5.

32. Bose M, Lambert JD, Ju J, Reuhl KR, et al. The major green tea polyphenol, (2)-epigallocatechin-3-gallate, inhibits obesity, metabolic syndrome, and fatty liver disease in high-fat-fed mice. J Nutr 2008; 138:1677-83.

33. Kanarek RB, Orthen-Gambill N. Differential effects of sucrose, fructose and glucose on carbohydrate-induced obesity in rats. J Nutr 1982; 112:1546-54.

34. Moura RF, Ribeiro C, de Oliveira JA. Metabolic syndrome signs in Wistar rats submitted to different high fructose ingestion protocols. Brit J Nutr 2009; 101:1178-84.
35. Busserolles J, Gueux E, Rook E, et al. Substituting honey for refined carbohydrates protects rats from hypertriglyceridemic and prooxidative effects of fructose. J Nutr 2002; 132:3379-82.

36. Gill HS, Guarner F. Probiotics and human health: A clinical perspective. Postgrad Med J 2004; 80:516-26.

37. Han SY, Huh CS, Ahn YT et al. Hepatoprotective effect of lactic acid bacteria, inhibitors of $\beta$-glucuronidase production against intestinal microflora. Arch Pharm Res 2005; 28:325-9.

38. Rodas BZ, Gilliland SE, Maxwell CV. Hypocholesterolemic action of Lactobacillus acidophilus ATCC 43121 and calcium in swine with hypercholesterolemia induced by diet. J Dairy Sci 1996; 79:2121-8.

39. Wang Y, Xu N, Xi A. Effects of Lactobacillus plantarum MA2 isolated from Tibet kefir on lipid metabolism and intestinal microflora of rats fed on high-cholesterol diet. Appl Microbiol Biothech 2009; 84:341-7. 